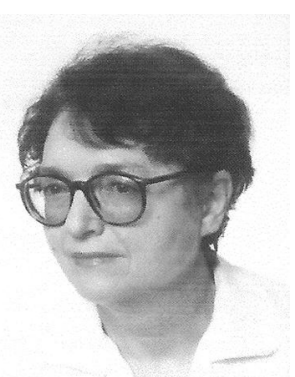

\title{
Danuta Madeyska
}

Danuta Madeyska - profesor zwyczajny, arabistka i islamistka, historyk świata arabskiego i literaturoznawca, wieloletni wykładowca w Katedrze Arabistyki i Islamistyki Uniwersytetu Warszawskiego, a w latach 2006-2010 Pracowni Języka i Kultury Arabskiej UMK. Badaczka historii świata arabskiego okresu klasycznego i osmańskiego oraz współczesnej historii tego obszaru, a także ich polityki oraz stosunków międzynarodowych, autorka podręczników akademickich z tej dziedziny. Ważniejsze publikacje: Poetyka siratu: studium o arabskim romansie rycerskim (Warszawa 1993), Poetics of the Sirah: a study of the Arabic chivalrous romance (Warszawa 2001), Historia świata arabskiego: okres klasyczny, od starożytności do końca epoki Umajjadów (750) (Warszawa 1999), Historia świata arabskiego: okres osmański 1516-1920 (Warszawa 1988), Liban (Warszawa 2003, Historia współczesna świata arabskiego (Warszawa 2008). 


\section{Beduini i mieszkańcy miast na przykładzie Siratu Zat al-Himma* i Księgi tysiąca i jednej nocy ${ }^{* *}$}

DOI: http://dx.doi.org/10.12775/LC.2014.010

epoce powstawania pisemnych wersji fabularnie ujednoliconych arabskich romansów rycerskich (siratów) oraz zbiorów opowieści, które złożyły się następnie na Księgę tysiąca i jednej nocy, zapożyczano różnorodne wątki z krążących oddzielnie ustnych wersji legend, baśni różnego pochodzenia, opowieści rycerskich o charakterze religijnym lub świeckim o popularnych postaciach lub znanych wydarzeniach albo włączano je w całości do większych dzieł. Rezultatem tego procesu jest zjawisko występowania tych samych wątków $\mathrm{w}$ różnorodnych tematycznie i strukturalnie dziełach typu adabowego, historycznego lub geograficznego należących do literatury wysokiej oraz niezmiernie popularnych dziełach, adresowanych do niepiśmiennego audytorium, do których zaliczyć można siraty lub Księgę tysiąca i jednej nocy. Według świadectwa E. W. Lane'a ${ }^{1}$ rękopisy niektórych pisemnych wersji opowiadacze czytali głośno w kawiarniach, ulubionych miejscach towarzyskich spotkań.

Przypuszczać należy, że badacz, który zadałby sobie trud uważnego przestudiowania wszystkich zachowanych, zwykle bardzo obszernych siratów oraz zbiorów bajek i opowieści ramowych, znalazłby w nich liczne wspólne wątki, epizody i całe opowieści, o czym świadczą ukazane poniżej rezultaty porównania ze sobą dwóch tylko utworów.

Stare opowieści beduińskie długo krążyły w ustnych przekazach, zanim weszły w różnych epokach do większych dzieł. W różnorodnym, anonimowym materiale, składającym się na Księgę tysiaca i jednej nocy zarówno Opowieść o Omarze an-Numanie ${ }^{2}$, jak i Opowieść o Adżibie i Gharibie $e^{3}$ uderzają swoją odmiennością od reszty utworów. Obie opowieści krą-

* Sirat al-amira Dat al-Himma wa-waladiha al-amir Abd al-Wahhab wa-al-amir Abu Muhammad al-Battal wa-Ukba szajch al-Dallal wa-Szumadris al-muhtal, cz. 1-70, Al-Kahira [brak daty wydania].

** Księga tysiq̨ca i jednej nocy, wstęp i red. T. Lewicki, t. 1-9, Warszawa 1973.

1 E. W. Lane, The Manners and Customs of the Modern Egyptians, London 1944 (pierowdruk 1836), s. 397-431.

${ }^{2}$ Księga tysiqca i jednej nocy, t. 2, s. 7-369.

3 Opowieść o Adżibie i Gharibie, [w:] ibidem, t. 5, s. 141-292. 
żyły początkowo jako samodzielne utwory ${ }^{4}$ i zostały włączone do zbioru w wiekach późniejszych ${ }^{5}$. Spośród nich na szczególną uwagę zasługuje Opowieść o Omarze an-Numanie z powodu swych szczególnych powiązań z Siratem Zat al-Himma. Stosunkowo wcześnie, bo w latach 20. i 30. ubiegłego wieku zwrócili na to uwagę Rudi Paret i Marius Canard, starając się odnaleźć historyczne prototypy Omara an-Numana i głównych bohaterów Siratu Zat al-Himma oraz ich związki z bizantyjskim eposem Digenis Akritas i tureckim Battalname ${ }^{6}$. M. Canard zbadał przy tym etapy kształtowania się epiki arabskiej i tureckiej opiewającej wojny ze światem chrześcijańskim i wykazal, że Opowieść o Omarze an-Numanie zamieszczona $\mathrm{w}$ Księdze tysiaca i jednej nocy była jej etapem ostatnim? ${ }^{7}$.

Podczas przechodzenia z poziomu literatury wysokiej, do której można zaliczyć wczesne siraty (Qissat Az-Zir Salim, Sirat Antara, Sirat Zat al-Himma, Hilalijja), do literatury ludowej, adresowanej do niższych warstw społecznych, przede wszystkim większości mieszkańców średniowiecznych miast, warstwa aksjologiczna tych utworów, do których można zaliczyć także późne siraty (Sirat az-Zahir Bajbars, Sirat Sajf Ibn Zi Jazan, Sirat Ali Az-Zajbak) uległa głębokim przekształceniom ${ }^{8}$.

Interesujące byłoby porównanie pewnych wątków wspólnych dla Siratu Zat al-Himma i Opowieści o Omarze an-Numanie i prześledzenie zmian, jakim uległ tekst późniejszy. Dotyczy to przede wszystkim sposobu przedstawienia tych samych wydarzeń, a także przekształceń charakteru niektórych postaci. Może to stanowić dobrą egzemplifikację różnic między wczesnymi siratami, do których materiału dostarczyły w znacznym stopniu opowieści beduińskie, a popularną literaturą miejską.

Około połowa tekstu Opowieści o Omarze an-Numanie (po odrzuceniu dwóch opowieści wtrąconych) jest wspólna z pierwszymi rozdziałami Siratu Zat al-Himma (cz. I, s. 6 - cz. IV, s. 75), niektóre zaś wątki są, przy zmienionej kolejności ich występowania i odmiennych imionach ich bohaterów, niemal identyczne w obu utworach. Omówię je tutaj według kolejności, w jakiej występują w Siracie.

\section{I. Śmierć brzemiennej z ręki wiarołomnego niewolnika}

\section{(Sirat, I, s. 6-9, 25; Opowieść, s. 50-54,367)}

Najwcześniejszy w Siracie jest wątek śmierci brzemiennej kobiety, którą zabija w drodze powrotnej do rodzinnych stron towarzyszący jej niewolnik. Punkt wyjścia tego wątku jest

${ }^{4}$ Zob. V. Chauvin, Bibliograhie des ouvrages arabes ou relatifs aux arabes publiés dans l'Europe chrétienne de 1810 à 1885, Liège 1892-1909, t. 3, s. 130 I 136.

5 Obszerną bibliografię bogatej literatury na temat Księgi tysiąca i jednej nocy zamieściła Mia Gerhardt, The Art of Story-Telling. A Literary Study of The Thousand and One Nights, Leiden 1963.

${ }^{6}$ R. Paret, Der Ritter-Roman von 'Umar an-Nu'man und seine Stellung zur Sammlung von Tausend und Eine Nacht, Tübingen 1927.

7 M. Canard, Delhemma, Sayyid Battal et Omar el-No'man, „Byzantion” 1937, XIl; Dhu'l Himma, [w:] El (New Ed.), II; Les principaux personnages du Roman de chevalerie arabe Dat al-Himma wa'l-Battal, "Arabica” 1961, VIII, f. 2.

8 Por. D. Madeyska, Arabskie romanse rycerskie, "Przegląd Orientalistyczny”1979, z. 2 (110). 
zupełnie odmienny w obu utworach. W Siracie Ar-Rabab brzemienna bohaterka jest żoną wodza beduińskiego plemienia Kilab, opiewanego w utworze. Po śmierci męża, tuż przed rozwiązaniem, postanawia ona wrócić do rodzinnego plemienia, obawiając się zemsty wrogów swego męża. W Opowieści bohaterką jest rumijska (bizantyńska) księżniczka Abriza, nawrócona na islam przez Szarkana, syna tytułowego bohatera Opowieści, króla Omara an-Numana. Przybywa ona wraz z Szarkanem do Bagdadu, aby uroczyście poślubić królewicza. Na królewskim dworze zostaje podstępnie zgwałcona przez króla Omara. W rezultacie staje się brzemienna i tuż przed rozwiązaniem postanawia uciec do rodzinnego kraju. W Siracie bohaterka zabiera ze sobą jednego niewolnika, którego zachowanie na początku nie zdradza złych zamiarów, a imię (Salam) daje fałszywe wyobrażenie o jego charakterze. W Opowieści bohaterce towarzyszy dodatkowo niewolnica Mardżana, która odegra ważną rolę w zakończeniu utworu. Niewolnik (czarny) nosi znaczące imię Ghadban, a jego zamiary są jasne od samego początku. W drodze próbuje on uwieść bohaterkę, która wybucha oburzeniem, co w konsekwencji przyśpiesza poród i Abriza rodzi syna. Zawiedziony niewolnik zabija bohaterkę i ucieka. Niemowlę ratuje przejeżdżający tamtędy przyszły opiekun dziecka: w Siracie wódz sąsiedniego plemienia, w Opowieści rumijski ojciec bohaterki. Chłopiec wyrasta nie znając swego pochodzenia i dowiaduje się o nim dzięki zawieszonemu na szyi: w Siracie amuletowi, zawierającemu wszystkie dane, w Opowieści perle, a wszystkie brakujące szczegóły wyjawia niewolnica Mardżana. Wątek ten kończy się w obu utworach identycznie: przykładnym ukaraniem wiarołomnego niewolnika przez dorosłego już syna zamordowanej bohaterki.

\section{Miłość do córki stryja \\ (Sirat, I, s. 85-II, s. 18; Opowieść, s. 330-347)}

Jest to wątek typowy dla starych opowieści beduińskich: bohater zakochuje się w córce stryja, opiewa ją w wierszach, wywołując gniew jej ojca, następnie wyrusza w świat, aby zdobyć $m a h r^{9}$, przeżywa liczne przygody, wraca z wielkim bogactwem i zdobywa rękę ukochanej. Powstała w epoce Umajjadów beduińska poezja miłosna powiela ten wątek, jednak opiewana wówczas miłość, tzw. „miłość uzryjska” jest niespełniona.

W Siracie akcja toczy się w Al-Hidżazie, w środowisku beduińskim, a wątek występuje na początku dzieła, w Opowieści rzecz dzieje się w środowisku miejskim pod koniec utworu. Bohater: As-Sahsah (w Siracie) / Kanmakan (w Opowieści) zakochuje się w Lajli / Kudiji Fakan; obie ukochane są rówieśniczkami bohaterów, obie określane są jako „córka stryja”. Ojciec bohatera: Dżunduba, wódz plemienia Kilab / król Dau al-Makan, zrzeka się władzy na rzecz swego brata, Attafa, ojca ukochanej bohatera, Lajli, / szambelana Sasana, męża swojej siostry, ojczyma ukochanej bohatera, Kudiji Fakan. Po śmierci ojca naszego bohatera opuszczona przez wszystkich jego matka znajduje schronienie i opiekę u żony aktualnie rządzącego, z tą różnicą, że w Siracie obie kobiety rodzą w tym samym czasie; jedna syna, druga córkę, a w Opowieści młodzi mają w tym czasie po dwanaście lat. Młodzi zakochują

\footnotetext{
${ }_{9}$ Dar małżeński płacony przez pana młodego.
} 


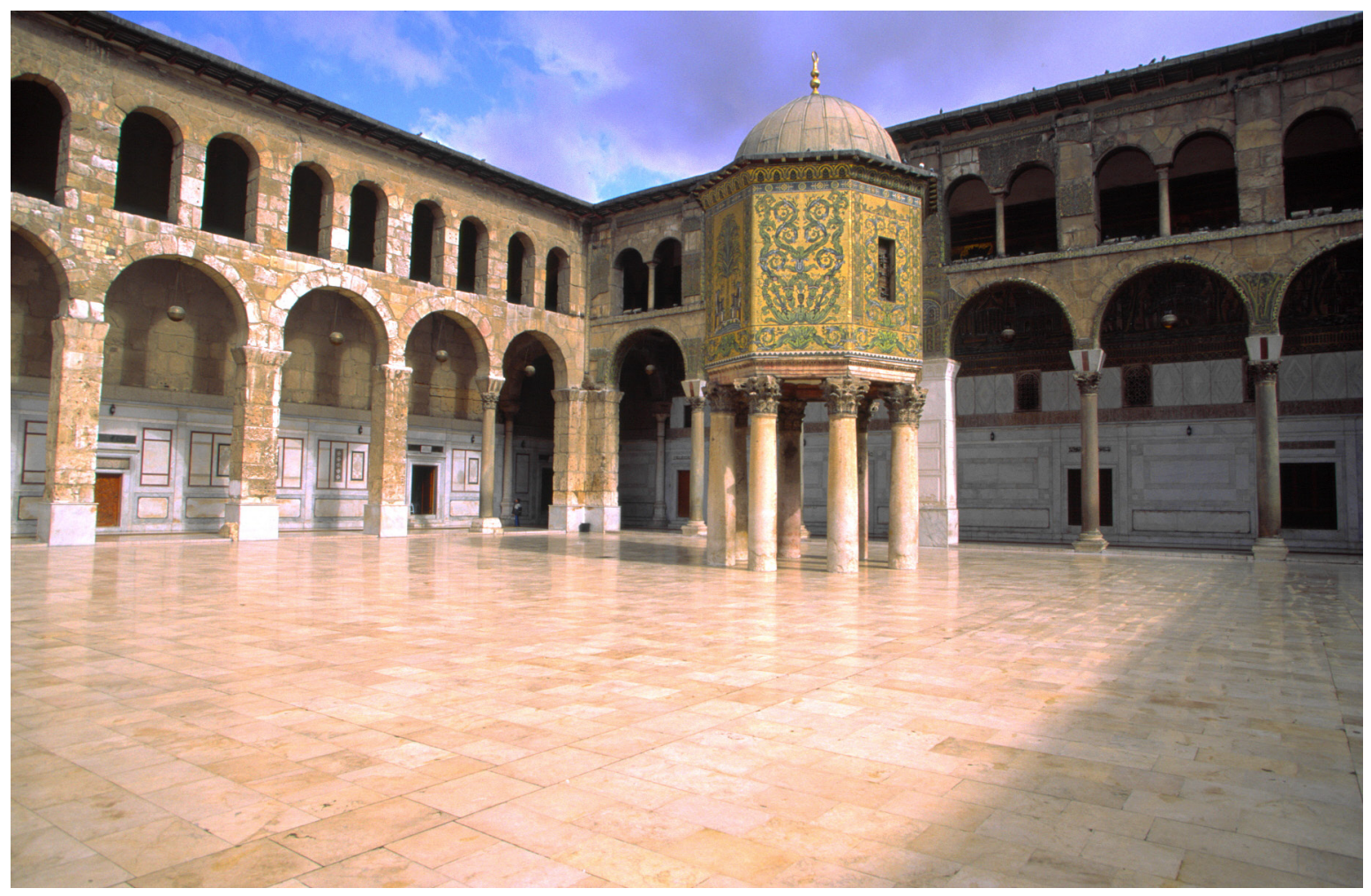

Kopuła Skarbu na dziedzińcu meczetu Umajjadów w Damaszku, Syria (fot. Z. Preisner)

się w sobie w wieku piętnastu lat, młodzieniec opiewa dziewczynę w wierszach i wywołuje tym gniew ojca/ojczyma ukochanej. Następuje rozdzielenie zakochanych; zaczynają spotykać się potajemnie. W osiemnastym roku życia bohater po raz pierwszy wyrusza w świat. Tchórzliwym towarzyszem bohatera jest w Siracie niewolnik, w Opowieści beduin. W drodze bohater spotyka ciężko rannego koniokrada, który umiera, przekazując mu skradzionego rumaka niezwykłej piękności. Następuje powrót bohatera, ogólny podziw i powrót do łask ojca/ojczyma ukochanej, który otrzymuje konia w darze. Młodzi zaczynają ponownie spotykać się potajemnie, sekret wychodzi na jaw i Attaf / król Sasan postanawia zabić młodzieńca. Bohater znowu wyrusza w świat, natyka się na stado, zabija pilnującego go strażnika (w Siracie jest nim niewolnik podobny do słonia, w Opowieści konny Turek) i zagarnia stado. W drodze powrotnej dogania go właściciel stada ze swymi ludźmi, który bierze go za przebraną po męsku dziewczynę, o którą się stara. Po odkryciu pomyłki bohater w walce i pojedynkach zabija wszystkich i wraca w triumfie. Prestiż jego znacznie wzrasta i zazdrosny Attaf / król Sasan postanawia go zabić. Dziewczyna zawiadamia o tym ukochanego. Młodzieniec wyrusza na polowanie, łowi dziesięć gazel, które następnie uwalnia. As-Sahsah / Kanmakan zostaje napadnięty przez przekupionych jeźdźców i zabija ich wszystkich; porzucone ciała znajduje wiarołomny opiekun bohatera. Tutaj wątek się rozchodzi. W Opowieści król Sasan zostaje schwytany i uwięziony przez mieszkańców Bagdadu, a wydarzenie 
to jest opisane jednym zdaniem bez podania powodu ${ }^{10}$. W Siracie epizod ten jest potraktowany znacznie szerzej: gdy As-Sahsah wychodzi na polowanie, stryj rusza za nim, aby go zabić. W drodze natyka się na oddział wrogiego plemienia, którego wodza kiedyś zabił. Dostaje się do niewoli i zostaje zabrany do siedziby plemienia. Na wieść o tym As-Sahsah wyrusza na pomoc stryjowi. Pozostawiwszy ludzi w ukryciu wjeżdża samotnie do obozowiska, ukryty pod zasłoną. W tym miejscu wątki się zbiegają; nasz bohater uwalnia nocą opiekuna i razem uciekają. W drodze następuje pojednanie. Na ich spotkanie wychodzą ludzie (w Siracie kobiety z tamburynami, w Opowieści mieszkańcy Bagdadu (sic!) z ukochaną naszego bohatera na czele ${ }^{11}$. Młodzieniec zostaje okrzyknięty największym rycerzem swego czasu, a jego opiekun ponownie postanawia go zabić. Przekupuje znaną i lubianą przez bohatera osobę (w Siracie jest nią czarny niewolnik, piastun Layli, w Opowieści niewolnica, starucha o szpetnej powierzchowności, piastunka obojga młodych), która ma go podstępnie zgładzić. Bohatera ratuje matka, ostrzeżona przez jego ukochaną. Tu wątki ponownie się rozdzielają. W Siracie zamachowiec zostaje zabity, stryj nie rezygnuje ze swego zamiaru, na pustyni podstępnie atakuje bohatera, lecz sam zostaje napadnięty przez lwa. As-Sahsah po raz kolejny ratuje mu życie i następuje ostateczne pojednanie. W Opowieści niewolnica jest bez żadnej przyczyny puszczona wolno: „Bakun zaś pojęła w swej przebiegłości, że matka Kanmakana wie o tym, co miało zajść. I odeszła swoją drogą"12; natomiast bohater opuszcza miasto i przyłącza się do zbuntowanego wezyra. Po dalszych przygodach, innych w obu utworach, młodzi pobierają się.

Beduiński wątek miłości do córki stryja potraktowany jest w Siracie znacznie szerzej. Odmienny charakter mają niektóre postaci. Działania bohaterów są w Siracie logicznie umotywowane. Pośredniczką między młodymi, a więc postacią pozytywną, jest w Siracie matka bohatera; w Opowieści odrażająca starucha: „Udał się do pewnej obrzydliwej, rozwiązłej, chciwej i chytrej staruchy"13. W Siracie As-Sahsah zabija właściciela stada, ponieważ okazał się nim sprawca śmierci jego ojca, a stryj Attaf zostaje pochwycony do niewoli przez syna człowieka, którego kiedyś zabił (prastary beduiński obowiązek zemsty). W środowisku beduińskim zajęcie się rozbojem przez As-Sahsaha dla zdobycia wystarczającego bogactwa na wiano za ukochaną osadzone są w starej tradycji napadów międzyplemiennych i nie są niczym nagannym, natomiast te same działania księcia Kanmakana, mieszkańca Bagdadu nabierają dwuznacznego charakteru.

\section{Przygoda z księżniczką rumijską \\ (Sirat, III, s. 72 - IV, s. 21; Opowieść, s. 14-39)}

Następny epizod dotyczy w Siracie późniejszych wydarzeń, a bohaterem jest znany już As-Sahsah, w Opowieści zaś Szarkan, syn tytułowego bohatera utworu, Omara an-Numana. Rzecz dzieje się w czasie wyprawy na Bizancjum (Ar-Rum). W Siracie wyprawą na Konstan-

\footnotetext{
10 Opowieść, s. 341.

11 Ibidem, s. 342.

12 Ibidem, s. 348.

13 Ibidem, s. 330.
} 
tynopol dowodzi Maslama, syn kalifa Abd al-Malika (obie postacie historyczne), w Opowieści młody królewicz Szarkan dowodzi oddziałami wraz z wezyrem swego ojca. Akcja rozwija się identycznie w obu utworach. Po przybyciu nad zatokę As-Sahsah / Szarkan odłącza się nocą od wojska i w czasie jazdy zasypia na koniu. Koń dowozi go na łąkę w pobliże pewnej twierdzy, gdzie bohater jest świadkiem osobliwej zabawy pewnej pięknej księżniczki rumijskiej ze swymi niewolnicami: mocuje się z nimi kolejno, każdą obala na ziemię i wiąże. W Opowieści występuje tu po raz pierwszy postać obmierzłej staruchy, która odgrywa ważną i złowrogą rolę w dalszej akcji. Nasz bohater trzykrotnie próbuje pokonać dziewczynę, lecz przegrywa zapasy i księżniczka zaprasza go do twierdzy, gdzie spędza samotną noc, a następnie spędza z nią cały dzień, ucztując i recytując wiersze rumijskie i arabskie. Sielanka zostaje przerwana wtargnięciem zbrojnych patrycjuszy, którzy zamierzają schwytać bohatera. Księżniczka posłuszna prawu gościnności odmawia wydania gościa. Bohater zabija w pojedynku wodza patrycjuszy i jego brata, a następnie w walce większość z nich, a pozostali uciekają. Księżniczka wzywa odźwiernych, łaje ich za wpuszczenie nieproszonych gości do twierdzy i nakazuje bohaterowi, aby ich pozabijał. W Siracie bohater wstawia się za nimi i ocala im życie, w Opowieści wykonuje jej polecenie. Po tym wydarzeniu księżniczka przechodzi na stronę muzułmanów.

Dalszy ciąg jest tematem opowiedzianej już historii. W Siracie księżniczka Aluf przechodzi na islam i poślubia Maslamę, w Opowieści księżniczka Abriza przybywa do Bagdadu, aby poślubić Szarkana, zostaje podstępnie zgwałcona przez króla Omara an-Numana, brzemienna ucieka do swego kraju, w drodze zostaje zabita przez niewolnika (epizod I).

Przygoda z księżniczką rumijską jest zbieżna w obu utworach (aczkolwiek w Siracie jest potraktowana obszerniej), zarówno pod względem następstwa wydarzeń, jak i większości szczegółów; niektóre fragmenty są identyczne. Poetyckie wstawki też częściowo się pokrywają. Występujące różnice nie mają wpływu na tok akcji, świadczą jednak o odmiennym charakterze obu utworów. W Opowieści nie ma sceny, obszernie opisanej w Siracie, nakłaniania pobożnego bohatera do picia wina (zabronionego w Koranie), nie istnieje także scena, dwukrotnie powtórzona i zakończona sukcesem (przewijająca się w różnych sytuacjach i z różnymi postaciami przez cały Sirat), nakłaniania rumijskiej księżniczki do przejścia na islam. Pojawiająca się w Opowieści postać przewrotnej staruchy, jak już wspomniałam, jest potrzebna do dalszych wydarzeń i odpowiadać będzie negatywnemu bohaterowi następnego epizodu, paralelnego w obu utworach.

\section{Podstępy chytrego mnicha / staruchy (Sirat, IV, s. 37-75; Opowieść, s. 146-200)}

Dość obszerna historia opisująca diabelskie podstępy chytrego mnicha (w Opowieści chytrej staruchy) rozpoczyna się w momencie przybycia wojsk muzułmańskich do kraju Ar-Rum. W Siracie jest to kontynuacja przygody z księżniczką rumijską, w Opowieści wydarzenia te dotyczą innej wyprawy wojennej. Strategia i taktyka wrogich wojsk jest jednakowa w obu utworach: wojska rumijskie rozdzielają się, główne siły przyjmują na siebie pierwsze uderzenie, pozostała część wojsk płynie morzem, zachodzi obóz muzułmanów od tyłu i ata- 


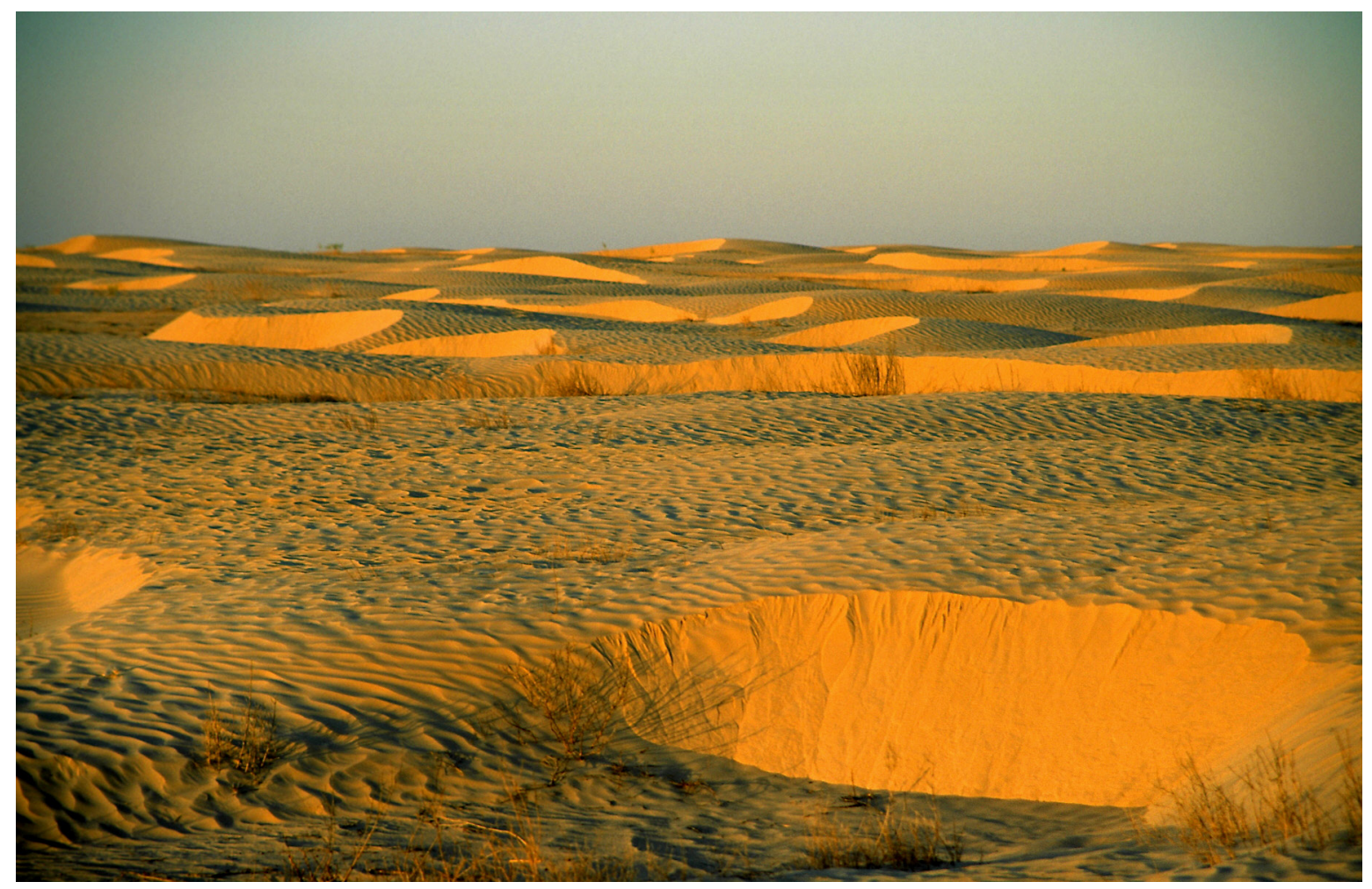

Pole wydmowe na Synaju (fot. Z. Preisner)

kuje znienacka, paląc namioty. Scena ta jest obszernie i logicznie opisana w Siracie; muzułmanów od klęski ratuje przybycie w ostatniej chwili oddziałów As-Sahsaha i Maslamy. Opowieść relacjonuje to jako zdradziecki plan rozgromienia muzułmanów, podsunięty królowi rumijskiemu przez przewrotną staruchę Zat ad-Dawahi i kończy paroma nie bardzo logicznymi zdaniami: „A gdy wojska muzułmańskie natarły na nich w tej dolinie, nie zauważyli nawet, kiedy ogień zajął ich namioty, a miecze pracowały wśród ciał. Później przybyły armie Bagdadu i Chorasanu...”"14. Pierwsze starcie kończy się zwycięstwem muzułmanów. Następnego dnia bitwa rozpoczyna się pojedynkiem (motyw obiegowy w opowieściach rycerskich) wodza wrogiego wojska (w Opowieści natartego i okadzonego kałem wielkiego patriarchy; w Siracie tylko okadzonego) z naszym bohaterem: As-Sahsahem / Szarkanem, który przed walką wygłosił wiersz. Wróg nie zrozumiał i przeżegnał się (salaba ala wadżhihi); w Opowieści „uderzył się dłonią po czole, z czcią dla krzyża nakreślonego na nim, i pocałował następnie swą dłoń” ${ }^{15}$. Wojska rumijskie ponoszą klęskę. W czasie bitwy wyróżnia się walecznością pewien rycerz ukryty pod zasłoną, który w Siracie okazał się księżniczką rumijską z poprzedniego epizodu, w Opowieści bratem bohatera. Rozgromione resztki woj-

\footnotetext{
14 Ibidem, s. 146.

15 Ibidem, s. 150.
} 
ska wroga uciekają do Konstantynopola i w tej krytycznej dla nich chwili do akcji wchodzi chytry mnich Szammas (w Opowieści: przewrotna starucha Zat ad-Dawahi) z szatańskim planem wymordowania wodzów muzułmańskich. Szammas / Zat ad-Dawahi, przebrany za świątobliwego ascetę, udał półżywego męczennika uwolnionego z rąk mnichów. Podstęp się udaje, zamachowiec zdobywa zaufanie wodzów i wprowadza ich w zasadzkę. Wodzowie dostają się do niewoli, a zamachowiec unika zdemaskowania. W nocy As-Sahsah / Szarkan oswobadza się z więzów i uwalnia swych towarzyszy. Nadciąga armia muzulmańska i zadaje klęskę Rumijczykom. Kolejne intrygi czynione przez mnicha / przewrotną staruchę nie udają się i armia dociera pod Konstantynopol.

Tutaj wątki się rozdzielają. W Siracie następuje obszerna scena przybycia na pomoc Rumijczykom wojsk króla Franków, który wyzywa As-Sahsaha na pojedynek i zostaje zabity. Rumijczycy ponoszą klęskę i chronią się do miasta. Dalsze wrogie działania chytrego mnicha / przewrotnej staruchy są odmienne w obu utworach, chociaż kończą się niepowodzeniem. W Opowieści Szarkan zostaje ciężko ranny w pojedynku z królem rumijskim, a starucha podstępnie go zabija. Inne jest też zakończenie wojennej wyprawy. W Siracie muzułmanie zdobywają Konstantynopol, w Opowieści odstępują od miasta i wracają do Bagda$\mathrm{du}^{16}$. Wspólny jest natomiast w obu utworach los chytrego mnicha / przewrotnej staruchy: zostają zdemaskowani i ukrzyżowani (Sirat, V, s. 25; Opowieść, s. 369).

Ten obszerny szereg zdarzeń, skomplikowany w obu utworach jest w Siracie jaśniej i logiczniej skonstruowany. Wynika to głównie z drobiazgowego opisu poszczególnych czynności, co jest cechą charakterystyczną wszystkich arabskich romansów rycerskich.

Pozostaje do rozstrzygnięcia kwestia wzajemnych zapożyczeń. Uczeni badający Księgę tysiąca i jednej nocy wysuwają przypuszczenie, że Opowieść o królu Omarze an-Numanie, pierwotnie krążąca w ustnych przekazach jako samodzielna całość, została włączona do Księgi znacznie później, przypuszczalnie podczas sporządzania pisemnej wersji. Przypuszczenie to opiera się na jej odmiennym od reszty Księgi realistycznym charakterze, pozbawionym niemal zupełnie czarodziejskich elementów, którymi odznaczają się baśnie z tego zbioru. Niemożliwe jest ustalenie, jaka była ustna wersja tej, jeszcze krążącej oddzielnie, opowieści beduińskiej, zanim dostała się do Siratu i Księgi. Wiadomo tylko, że tego typu utwory pozostawały w obiegu w ustnej formie już w IX-XI wieku, a ich pisemna redakcja została sporządzona w XIV-XVI wieku, w okresie panowania Mameluków. Przypuszczam jednak, że ustna wersja Opowieści została włączona do Siratu Zat al-Himma znacznie wcześniej, niewykluczone także, że pisemna wersja Opowieści została wzbogacona o epizody zaczerpnięte z Siratu. Jedyną wskazówką może być przedstawiona analiza treści i formy obu utworów.

Im wcześniejsza wersja, tym język jest prostszy, styl bardziej rozwlekły, głównie na skutek drobiazgowych opisów poszczególnych czynności, typu „wyszła i szła, aż doszła do [...] i weszła..... W rezultacie kolejne sceny są ze sobą powiązane, dokładnie umotywowane i logicznie wynikają jedna z drugiej. W miarę upływu czasu przekazywane ustnie opowieści przechodzą do środowiska miejskiego, które nie bardzo już rozumie realia beduińskie. Rezultatem zmiany samych narratorów - opowiadaczy, wywodzących się już z miast, jest

16 Ibidem, s. 303. 
zmiana samego tekstu. Jasny i logiczny tok akcji zaczyna się gmatwać, niektóre drobne, lecz istotne szczególy wypadają, przez co akcja staje się niekiedy niezrozumiała.

Charakterystyczna jest zmiana stosunku do beduinów. Opiewani przez wczesne siraty ${ }^{17}$ (Sirat Antara, Sirat Zat al-Himma, Kissat Az-Zir Salim, Hilalijja) wspaniali rycerze pustyni zmieniają się w nieokrzesanych tchórzliwych prostaków, co widać na przykładzie beduina, towarzysza Kanmakana z omawianej Opowieści z Księgi tysiąca i jednej nocy.

Główna różnica wypływa z odmiennego światopoglądu i systemu wartości we wczesnych siratach i Księdze tysiąca i jednej nocy. Te pierwsze przesycone są głęboką religijnością i często przewija się w nich znamienna charakterystyka głównego bohatera: „W dzień walczy, noc spędza na modlitwie”. Miały one być dla słuchaczy przykładem niesłychanego bohaterstwa arabskich pustynnych rycerzy, walczących zgodnie z przykazaniami Koranu z niewiernymi fi sabil Allah („na ścieżce Boga”) i rozszerzających obszary panowania islamu. Bawiąc słuchacza przygodami swoich bohaterów, Sirat Zat al-Himma ${ }^{18}$ zawiera w istocie o wiele głębsze treści. Niebezpieczeństwo zagraża państwu nie tylko ze strony wrogich państw. Sprzedajność, brak jedności w szeregach muzułmańskich bohaterów stanowią często znacznie większą groźbę; konflikty nawet między pozytywnymi bohaterami powodują nieuchronnie ich militarną klęskę i dostanie się w ręce wroga.

Tego pierwiastka nie ma w Księdze tysiąca i jednej nocy. Służyła ona, tak jak i inne miejskie opowieści krążące osobno, tylko rozrywce, zabawieniu słuchacza, zadziwieniu go niezwykłością relacjonowanych wydarzeń. Księga przesycona jest erotyzmem, młode kobiety ukazane są na ogół jako bezwolne narzędzia w rękach mężczyzn, a stare jako obmierzłe staruchy, uosobienie wszelkiego zła i przewrotności. Pośredniczka między parą zakochanych, postać pozytywna w Siracie, w Opowieści występuje jako „pewna obrzydliwa, rozwiązła, chciwa i chytra starucha”. Tych cech nie można umotywować tokiem akcji, ponieważ odgrywa ona, tak jak w Siracie, również pozytywną rolę. Postać najemnego mordercy, w Siracie czarnego niewolnika, zmienia się w Opowieści w staruchę: „niewolnica ta była jedną z najbardziej przewrotnych staruch, której wiara nie pozwalała stronić od zła”. W innym epizodzie Siratu postać przewrotnego mnicha ${ }^{19}$, który uknul szatański plan i w przebraniu świątobliwego ascety przedostał się do obozu muzułmańskich wojsk i zdobył zaufanie wodzów, w Opowieści występuje jako starucha, opisana niezwykle obrazowo: „Miała ona usta cuchnące i czerwone powieki, i żółte policzki w nieprzeniknionej twarzy. Spojrzenie miała cielęce, a ciało parszywe, włosy zaś szare. Plecy miała garbate, cerę bezbarwną i z nosa jej ciekło".

We wczesnych siratach rolę czarnych charakterów odgrywają z reguły mężczyźni, w większości niewolnicy. Opowieść zawiera kilka obscenicznych scen, opowiedzianych dosadnie i bez osłonek, na przykład scena zgwałcenia nawróconej na islam rumijskiej księżniczki przez tytułowego bohatera Opowieści, postaci przecież pozytywnej. Tego charakteru nie posiadają paralelne epizody Siratu. Sceny erotyczne uderzają tam swoim purytanizmem. Muzułmanka jest absolutnym tabu dla szlachetnego rycerza ${ }^{20}$, a obscena oddane są przez omówienie. Jest ich zresztą wyjątkowo niewiele jak na 7-tomowe dzieło. Opowiadacz uni-

\footnotetext{
17 Które są przedmiotem moich badań, zob. D. Madeyska, Poetyka siratu, Warszawa 1993.

18 Tytułowa postać jest w jednej osobie kobietą, wodzem plemienia i niepokonanym rycerzem.

19 Wybranie go na negatywnego bohatera można łatwo wytłumaczyć trwającymi (z przerwami) kilka wieków wojnami arabsko-bizantyjskimi, zob. D. Madeyska, Wojny arabsko-bizantyjskie, „Przegląd Orientalistyczny" 1977, z. 3 (103).

20 Poganki lub kobiety wyznające inną wiarę nie podlegają takiej ochronie.
} 
Mieszkanka oazy

w pobliżu klasztoru

św. Katarzyny na Synaju

(fot. Z. Preisner)

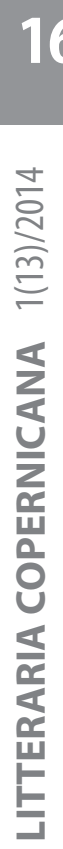

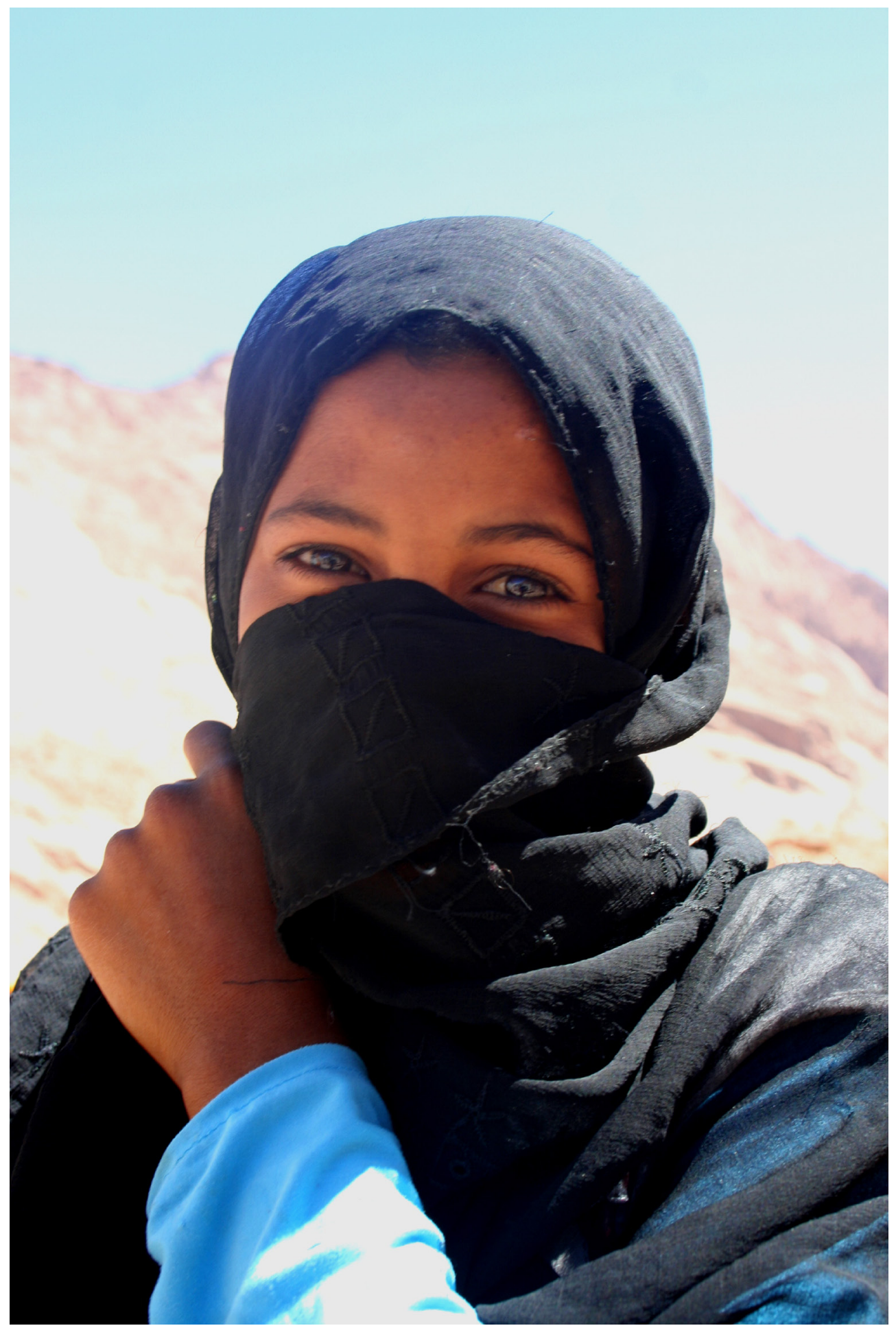


ka wulgaryzmów, na przykład wspomina tylko, że przed bitwą duchowni mieli zwyczaj okadzać wodzów rumijskich kałem wielkiego patriarchy, wierząc w jego cudowne właściwości, podczas gdy w Opowieści wodzowie są nacierani ekskrementami, a sama czynność jest dokładnie opowiedziana. Element erotyzmu w Opowieści występuje nawet tam, gdzie go nie ma w Siracie: opisy przebiegłości i szkaradnej powierzchowności chytrego mnicha i przewrotnej staruchy są identyczne, jednakże postać w Siracie nie posiada perwersyjnych skłonności, cecha, którą z upodobaniem opisuje narrator Opowieści. Znamienna jest różnica epizodu III: (Przygoda z księżniczką rumijską). W Siracie obawy bohatera, który wzbrania się ucztować, powodowane są troską, aby spośród różnorodności potraw nie zjeść przypadkiem wieprzowiny; w Opowieści bohater obawia się otrucia, co grzeszy brakiem logiki, gdyż księżniczka mogła zabić go wcześniej, gdy pokonała go w pojedynku. Dwie strony zabiera narratorowi opis nakłaniania bohatera do picia wina, a gdy ten wreszcie ulega namowom, w odróżnieniu od Opowieści, nie upija się.

Warto zauważyć, że późne siraty, pochodzące z XV-XVII wieku i powstałe w środowisku miejskim, są bardzo podobne do Księgi tysiąca i jednej nocy. Zamiast szlachetnego beduińskiego rycerza, wodza plemienia, głównym bohaterem jest najczęściej feudalny władca lub sprytny rzezimieszek, którego przygody mają bawić audytorium, nie zaś umacniać go moralnie. Najbardziej podziwianą cechą charakteru zamiast pobożności, niezwykłej odwagi lub wręcz brawury oraz nadludzkiej siły fizycznej, jest inteligencja i przebiegłość. Zamiast rycerskich metod walki z niewiernymi, dominujący jest duch nietolerancji religijnej: innowiercy przedstawiani są w skrajnie negatywnym świetle, a w związku z tym na uznanie zasługują wszelkie środki prowadzące do zwycięstwa, nawet te, prowadzące do łamania zasad islamu.

Pozostaje kwestią otwartą, czy te same wątki występujące w siratach i Księdze tysiąca i jednej nocy powstały jako rezultat korzystania z tych samych opowieści krążących osobno, czy też jest to wynikiem zapożyczania przez twórców lub redaktorów Księgi poszczególnych opowieści lub epizodów bezpośrednio z siratów. Problem ten zasługuje z pewnością na dokładne zbadanie. 